\title{
21 世紀初頭雑感：長寿と平和を考える
}

琉球大学医学部保健学科保健社会学教室

崎原 盛造
世紀を超えて新しいミレニアムを経験できるこ とはすばらしいことである．21世紀は，どのよ うな社会になるであろうか。国民の生活は？ 超 高齢社会で安心して暮らせるだろうか？ 地球の 温暖化は防止できるだろうか？ アルビン・トフ ラーが 20 年前に予言したとおり（『第三の波』）, 米国の保険, 教育, 家庭の組織が崩壊しつつあり, 日本でも同様の現象が起きている.WHOのスロ ーガンであった “Health For All by the Year 2000”は達成されず, “Health For All in the 21st Century” へ看板を書き換えて持ち越された。人 間の知恵と理性がうまく機能し, 紛争のない, 飢 餓から解放された，健康で幸せな生活ができるよ うになるであろうか？凡人には先のことは読め ないが，好ましい方向へ進んでほしいと願わずに はいられない. 少なくとも地球村（グローバル・ ビレッジ）の一貝としての責任は果たしたいと思 う.

20 世紀は，激動の 100 年であった。世界レベル では, 第 1 次 - 第 2 次世界大戦, 多数の植民地国 家の独立, ソ連邦の崩壊に続く東欧諸国の民主化, 冷戦の終結, EU成立, 南北朝鮮の首脳会談等の 国際政治をめぐる大変動があり，科学技術分野で は抗生物質の発見, 天然痘の根絶, 宇宙船アポロ による月面着陸，通信技術の発達，交通手段の高 速化, 情報科学の発達, 20 世紀末におけるヒト ゲノム解読という偉業があった。

ナショナルレベルでは, 第2 次世界大戦におけ る敗戦が，明治維新に次ぐ社会体制の大変動と価 值観の転換をもたらす契機となった．天皇の人間 宣言, 新憲法制定, 中高等教育の普及, 高度経済 成長, 生活環境の整備, 公衆衛生サービス網の整 備，国民皆保険による医療サービスの普及等があ り，生活水準が飛躍的に向上し，アジアで唯一
「先進国」の仲間入りを果たし，世界一の長寿国 となった。

ローカルレベルでは，各地を通じて多様であろ う. 国内で他と大きく異なる 20 世紀後半を歩ん だ沖縄はどうだろうか.これまでの自分史で，少 年期は激しかった太平洋戦争を挟んで，生きるこ とで精一杯の生活を過ごし, 青年期の戦後は米国 の統治という異民族支配を経験した。ベトナム戦 争では多くの米兵が沖縄から飛び立ち，泥だらけ の戦車やトラックで州ってくる海兵隊員を身近で 見て, 戦争を体で感じつつ 20 代を過ごし, アメ リカでの生活も経験した. 現在も米軍の基地が集 中するこの地域が激動する世界の政治経済の荒波 に翻弄されつつも，世界一長寿国日本の中でも平 均寿命は長く, 百歳以上の超長寿者も多い地域に なった．まさに感慨深く，また平和の尊さを痛感 するこの頃である.

WHO 憲章前文における平和と健康の関係につ いての記述を読み直してみた．どのような背景か ら「平和と健康」の内容が前文に取り入れられた のか定かではないが，第2 次世界大戦におけるナ チズムによるユダヤ人迫害と大虐殺が示すリーダ 一の「社会的健康」が反映しているのだろうか. 国家のリーダーの「健康的」な思想が平和を実現 するためには必要であるという認識が基盤にあっ たと推測することは読み過ぎだろうか.しかし， 逆に「平和でなければ，人々の健康を守ることは できない」とも言える.

第 2 次世界大戦は，アメリカ大陸を除く地球上 で戦闘が展開され, 戦闘員のみならず民間人を含 めた人的損失は 5,000 万人とも 6,000 万人とも言わ れている.日本の人的損失も大きく，戦闘員 150 万人余, 民間人約 30 万人が戦争で直接生命を失 った．銃後の犠牲者を含めるとそれよりはるかに 
多くなることは言うまでもない．わずか数年間で これだけ多数の人びとが生命を奪われたのであ る.その中でも, 広島と長崎は原爆による犠牲者 を，沖縄では「鉄の暴風」と表現された空曝と陸 上で繰り広げられた激戦で犠牲者を多数出した。

太平洋戦争でとくに悲惨な戦場となった沖縄本 島南部には平和祈念公園がある，その一角に沖縄 戦で犠牲となったすべての人びとの名前を刻銘し た「平和の磯（いしじ）」がある，戦闘員も民間 人も，日本人はもちろんのことだが敵であったア メリカ人も, 日本人として闘った朝鮮や台湾の 人々も. そして沖縄の多数の民間人も。このよう な敵味方区別なく犠牲者の名前が刻銘された記念 碑は世界でも他には無いであろう. 多くの人がぜ ひ一度はこの「平和の礎」を訪れ，いのちの尊さ を思いつつ「平和」のために祈りをささげてほし いと願う次第である。

話題を長寿に戻すと, 沖縄県は1995年に国内 外の著名な長寿研究者を招き,「世界長寿地域」 宣言を行った。世界一の長寿地域とは言えないま でも，日本の中で長寿地域であることに異論はな いであろう。「長寿」は沖縄の観光産業の目玉商 品であり，「長寿」に関連する特産品も続々と開 発されている. しかし, 沖縄の人びとがなぜ長寿 なのか，その理由はあまりはっきりしない。いろ いろな理由が挙げられている. 温暖な地域や食べ 物から人々の性格, 強い親族関係網等など. しか し，これらを実証した研究報告はまだない。
これまで沖縄の長寿要因探究を目指した研究の ほとんどは, 仮説探究型の横断研究であった。全 国的な縦断研究の一部として行われている研究も あるが，成果はまだ出ていない，筆者も横断研究 で高齢者の心理社会的要因について研究してきた が, 現在は縦断研究プロジェクトを組織してすす めている段階であり，成果を出すにはまだ時間が かかる.よく考えてみると，これまで沖縄で展開 された長寿研究はミクロの部分に焦点をあてて, その背景にあるマクロの分野を考慮していなかっ たように思う。あるいは，それは当然の前提条件 として, 疾病構造や食生活という変数で集団の長 寿化を説明しょうとする，そして，背景となる環 境の整備や社会経済的な条件も個人単位で取り扱 う傾向が強い。

沖縄の人々の長寿要因に関する仮説モデルを構 築するとすれば，宿主要因と病因と環境要因の夕゙ イナミックな関連図を描くことになろう。その場 合の環境要因として, 教育水準, 所得水準, 環境 整備水準, 公媓衛生サービス網の整備, 医療サ一 ビスへのアクセシビリテイ，政治的安定等を忘れ てはならない。これら背景要因の整備が集団の長 寿化には不可欠である．米軍基地に囲まれた地域 で日々生活している者には，とくに地域が「平和」 で安定していることが長寿化の必要条件であると 思われる. 21 世紀が，すべての人にとって平和 で健康な地球社会であってほしいと念願する次第 である。 